\title{
Differential sister chromatid exchange response in phytohemagglutinin and pokeweed stimulated lymphocytes of goat (Capra hircus L)
}

\author{
D Di Berardino ${ }^{1}$, V Jovino ${ }^{1}$, A Crasto ${ }^{1}, \mathrm{MB} \mathrm{Lioi}^{2}$, \\ MR Scarfi ${ }^{3}$, I Burguete ${ }^{4}$ \\ ${ }^{1}$ Department of Animal Science, University of Naples 'Federico II', \\ 80055 Portici, Naples; \\ 2 Department of Animal Production, University of Basilicata, \\ Via $N$ Sauro 85, 85100 Potenza; \\ 3 CNR-IRECE, 80124 Naples, Italy \\ ${ }^{4}$ Department of Animal Production, University of Murcia, Espinardo, \\ 30071 Murcia, Spain
}

(Received 3 June 1996; accepted 21 January 1997)

Summary - A differential sister chromatid exchange (SCE)/cell response was observed between phytohemagglutinin (PHA) and pokeweed (PKW) stimulated blood lymphocytes of goat (Capra hircus L) exposed to final concentrations of $0.1,0.25,0.5,1,2.5$ and $5 \mu \mathrm{g} / \mathrm{mL}$ of BUdR. At $0.1 \mu \mathrm{g} / \mathrm{mL}$ of BUdR, the two mitogens gave very similar SCE/cell responses: the SCE mean values were $3.17 \pm 1.93$ for PHA and $3.28 \pm 1.76$ for PKW, and the frequency distributions fit very well the Poisson probability function with both mitogens. For $0.25 \mu \mathrm{g} / \mathrm{mL}$ and increasing BUdR concentrations, SCE/cell rates for pokeweed mitogen were significantly higher than those of PHA. At $5 \mu \mathrm{g} / \mathrm{mL}$ of BUdR, the SCE/cell response was $8.68 \pm 3.24$ for PKW and $6.96 \pm 3.45$ for PHA, and the difference was statistically significant $(P=0.0001)$; for both mitogens the SCE/cell frequency distributions fit the Poisson probability function only by adopting a Poisson 'mixture' model, which takes into account the presence of two different subpopulations of cells.

sister chromatid exchange / phytohemagglutinin / pokeweed / Poisson distribution / goat

Résumé - Effets différentiels de la phytohémagglutinine et du phytolaque sur les échanges entre chromatides sœurs chez les lymphocytes de la chèvre. Une réponse différentielle pour le nombre d'échanges entre chromatides sœurs a été observée entre les lymphocytes de chèvre (Capra Hircus L) stimulés par la phytohémagglutinine (PHA) ou le phytolaque $(P K W)$, après exposition à des concentrations finales de 0,1, 0,25, 0,5, 1, 2,5 et $5 \mu \mathrm{g} / \mathrm{mL}$ de BUdR. A $0,1 \mu \mathrm{g} / \mathrm{mL}$ de BUdR, les deux mitogènes ont donné une réponse 
$S C E$ / cellules très similaire : les valeurs moyennes ont été de $3,17 \pm 1,93$ pour PHA et de $3,28 \pm 1,76$ pour $P K W$, et les distributions de fréquences se sont très bien ajustées $\grave{a}$ une loi de Poisson pour les deux mitogènes. À partir de $0,25 \mu \mathrm{g} / \mathrm{mL}$, les réponses à PKW ont toujours été supérieures à celles correspondant à $P H A$. À partir de $5 \mu \mathrm{g} / \mathrm{mL}$ de $B U d R$, la réponse $S C E$ / cellule a été de $8,68 \pm 3,24$ pour $P K W$ et $6,96 \pm 3,45$ pour PHA et la différence a été significative. La distribution de fréquence pour l'ensemble des mitogènes s'est très bien ajustée à un mélange de deux lois de Poisson, correspondant aux deux populations de cellules concernées par chaque mitogène.

échange entre chromatides / phytohémagglutinine / phytolaque / comparaison / chèvres

\section{INTRODUCTION}

Sister chromatid exchange (SCE) is considered to be an important cytogenetic test for monitoring cytogenetic damage induced by environmental mutagens (Carrano et al, 1978) as well as for detecting chromosome instability conditions such as the Bloom syndrome in humans (Chaganti et al, 1974).

SCE studies reported in humans as well as in other mammalian species have largely indicated several important factors that can influence the frequency of SCE: BUdR concentration (Wolff and Perry, 1974; Kato, 1974), visible light (Ikushima and Wolff, 1974), type and amount of serum (Kato and Sandberg, 1977), exogenous viruses (Kato, 1977), cell cycle duration (Snope and Rary, 1979), growth temperature (Speit, 1980), composition and type of medium (Mutchinick et al, 1980), proportion of B and T lymphocytes (Lindblad and Lambert, 1981), antibiotics and serum (Das and Sharma, 1983), sex and age (Soper et al, 1984), dietary habits (Wulf et al, 1986), group, animal and BUdR treatment (Catalan et al, 1994; Iannuzzi et al, 1991a).

As is known, in vitro SCE studies are routinely carried out on peripheral blood lymphocytes stimulated either with phytohemagglutinin (PHA-M form) or with pokeweed (PKW) mitogens; the choice between them mainly depends upon how much hemagglutination is tolerated in the cultures; furthermore, pokeweed stimulates both classes of $\mathrm{B}$ and $\mathrm{T}$ lymphocytes, whereas phytohemagglutinin mainly stimulates $\mathrm{T}$ lymphocytes (Rooney and Czepulkowsky, 1986). Since the proportion of $\mathrm{B}$ and $\mathrm{T}$ lymphocytes in the blood and, to a greater extent, the rate of cell proliferation in the culture system have been indicated as important factors affecting the SCE/cell frequency (Santesson et al, 1979; Lindblad and Lambert, 1981) it is likely that the mitogen used in the culture system might well influence the final SCE/response.

The present study refers to the differential SCE/cell response observed in blood lymphocytes of goat (Capra hircus L) stimulated with PHA and PKW, and exposed to final concentrations of $0.1,0.25,0.5,1,2.5$ and $5 \mu \mathrm{g} / \mathrm{mL}$ of BUdR.

\section{MATERIALS AND METHODS}

Venous blood was aseptically collected from four goats (two males and two females) of the Jonica breed, reared in a farm located in Villa Literno, province of Caserta; the animals were clinically healthy and unrelated. 
Aliquots of $0.5 \mathrm{~mL}$ of whole heparinized blood were cultured at $37.5^{\circ} \mathrm{C}$ in $9.5 \mathrm{~mL}$ of RPMI 1640 medium (Gibco, Dutch modification), containing $10 \%$ fetal calf serum (Gibco), $0.1 \mathrm{~mL}$ L-glutamine (Gibco), $30 \mu \mathrm{L}$ of antibiotics and $50 \mu \mathrm{L}$ of fungizone.

For each animal 12 culture flasks were prepared, six stimulated with $0.1 \mathrm{~mL}$ phytoemagglutinin and six with $0.1 \mathrm{~mL}$ pokeweed mitogens (both from Gibco). After $36 \mathrm{~h}$ of growth, BUdR (Sigma, Saint Louis, MO, USA) was added at final concentrations of $0.1,0.25,0.5,1,2.5$ and $5 \mu \mathrm{g} / \mathrm{mL}$, respectively, for the PHA and PKW sets of flasks. The cultures were protected from light and allowed to grow for an additional $36 \mathrm{~h}$. Colcemid was added for the final $60 \mathrm{~min}$. Harvested cells were treated with hypotonic solution $(\mathrm{KCl}, 0.075 \mathrm{M})$ for $20 \mathrm{~min}$ at $37.5^{\circ} \mathrm{C}$ and fixed three times with methanol/acetic acid solution 3:1. Air dried slides were stained with a $0.2 \%$ acridine orange solution in phosphate buffer $(\mathrm{pH}=7.0)$ for 10 min, washed thoroughly in tap water, mounted in phosphate buffer and sealed with paraffin. SCEs were counted on 50 second cycle metaphase spreads, randomly scored for each animal, for each BUdR level. All scoring was performed by the same person.

Statistical note: For each BUdR dose and for both mitogens, data were analysed by means of Poisson's probability function, where the expected values were calculated using the following formula:

$$
P(x, \lambda)=\lambda^{x} \mathrm{e}^{-\lambda} / x !
$$

The chi square method was utilized to estimate the goodness of fit between observed and expected values. At the lowest BUdR dose Poisson's probability function fit very well the observed data for both PHA and PKW mitogens. Conversely, at the highest BUdR dose the fit was not observed for either mitogens. Therefore, at $5.0 \mu \mathrm{g} / \mathrm{mL}$ of BUdR a Poisson 'mixture' model was used. The 'Poisson mixture' is a non-linear regression function that allows the estimation, through the least squares method, of the unknown parameters $\gamma, \lambda_{1}, \lambda_{2}$, which minimize the expression

$$
P=\lambda_{1}^{x} \mathrm{e}^{-\lambda_{1}} / x !^{*} \gamma+\lambda_{2}^{x} \mathrm{e}^{-\lambda_{2}} / x !^{*}(1-\gamma)
$$

$\lambda_{1}$ and $\lambda_{2}$ represent the 'means', $\gamma$ and $(1-\gamma)$ the relative percentages of the two subpopulations of $\mathrm{B}$ and $\mathrm{T}$ lymphocytes. The fitness of the function is evaluated through the $R^{2}$ coefficients.

\section{RESULTS}

Table I shows the individual mean rates and standard deviations of SCE/cell at increasing doses of BUdR in PHA and PKW stimulated goat lymphocytes. At $0.1 \mu \mathrm{g} / \mathrm{mL}$ of BUdR the SCE/cell rates of the two mitogens are very similar $(3.28 \pm 1.76$ for PKW, $3.17 \pm 1.93$ for PHA), the difference not being statistically significant; at $5.0 \mu \mathrm{g} / \mathrm{mL}$ of BUdR, PKW values are significantly higher compared to the PHA ones $(8.68 \pm 3.24$ versus $6.96 \pm 3.45$, respectively) $(P=0.0001)$. From a BUdR concentration of $0.25 \mu \mathrm{g} / \mathrm{mL}$ and above, $\mathrm{PKW}$ values are significantly higher than PHA values.

Figure 1 visualizes the differential SCE/cell dose-response relationships between the two mitogens. Basically, the two curves start from the same level; PHA rates 
Table I. Individual mean rates and standard deviations of sister chromatid exchanges per cell (SCEs/cell) in phytohemagglutinin (PHA) and pokeweed (PKW) stimulated goat lymphocytes exposed to increasing doses of BUdR, scored on 50 cells for each BUdR level for each donor.

\begin{tabular}{|c|c|c|c|c|c|c|c|c|c|c|c|c|c|}
\hline \multirow{3}{*}{\multicolumn{2}{|c|}{ Donor }} & \multicolumn{12}{|c|}{$B U d R$ level $(\mu g / m L)$} \\
\hline & & \multicolumn{2}{|c|}{0.1} & \multicolumn{2}{|c|}{0.25} & \multicolumn{2}{|c|}{0.5} & \multicolumn{2}{|c|}{1.0} & \multicolumn{2}{|c|}{2.5} & \multicolumn{2}{|c|}{5.0} \\
\hline & & $P H A$ & $P K W$ & $P H A$ & $P K W$ & $P H A$ & $P K W$ & $P H A$ & $P K W$ & PHA & $P K W$ & $P H A$ & $P K W$ \\
\hline \multirow[t]{2}{*}{1} & $x$ & 3.44 & 3.4 & 3.1 & 4.54 & 3.7 & 6.72 & 5.14 & 6.46 & 6.02 & 7.58 & 6.66 & 8.06 \\
\hline & $\sigma$ & 1.89 & 1.56 & 1.79 & 2.31 & 1.89 & 2.59 & 3.27 & 2.79 & 2.66 & 2.90 & 3.13 & 3.30 \\
\hline \multirow[t]{2}{*}{2} & $x$ & 2.76 & 3.9 & 4.56 & 4.72 & 4.58 & 6.58 & 5.34 & 6.14 & 7.18 & 7.58 & 7.74 & 9.1 \\
\hline & $\sigma$ & 1.58 & 1.91 & 2.15 & 2.55 & 2.09 & 2.66 & 2.04 & 2.03 & 3.14 & 2.49 & 2.99 & 3.04 \\
\hline \multirow[t]{2}{*}{3} & $x$ & 3.26 & 2.54 & 5.04 & 4.74 & 5.48 & 4.56 & 5.3 & 3.58 & 6.5 & 5.86 & 7.12 & 8.66 \\
\hline & $\sigma$ & 2.31 & 1.80 & 2.55 & 2.39 & 2.71 & 2.25 & 3.40 & 2.11 & 3.69 & 2.56 & 4.20 & 2.98 \\
\hline \multirow[t]{2}{*}{4} & $x$ & 3.22 & 3.3 & 3.26 & 5.84 & 4.1 & 5.1 & 4.58 & 6.54 & 5.5 & 7.32 & 6.34 & 8.9 \\
\hline & $\sigma$ & 1.87 & 1.51 & 2.19 & 2.51 & 2.36 & 2.38 & 2.19 & 2.78 & 2.95 & 2.81 & 3.29 & 3.60 \\
\hline \multirow[t]{2}{*}{$1-4$} & $x$ & 3.17 & 3.28 & 3.99 & 4.96 & 4.46 & 5.74 & 5.09 & 5.68 & 6.3 & 7.08 & 6.96 & 8.68 \\
\hline & $\sigma$ & 1.93 & 1.76 & 2.32 & 2.48 & 2.36 & 2.63 & 2.79 & 2.73 & 3.17 & 2.77 & 3.45 & 3.24 \\
\hline \multirow{2}{*}{\multicolumn{2}{|c|}{$t$}} & \multicolumn{2}{|c|}{1.00} & \multicolumn{2}{|c|}{4.21} & \multicolumn{2}{|c|}{5.18} & \multicolumn{2}{|c|}{1.94} & \multicolumn{2}{|c|}{2.20} & \multicolumn{2}{|c|}{3.22} \\
\hline & $P$ & \multicolumn{2}{|c|}{$<0.25$} & \multicolumn{2}{|c|}{0.0001} & \multicolumn{2}{|c|}{0.0001} & \multicolumn{2}{|c|}{$<0.05$} & \multicolumn{2}{|c|}{$<0.01$} & \multicolumn{2}{|c|}{0.0001} \\
\hline
\end{tabular}

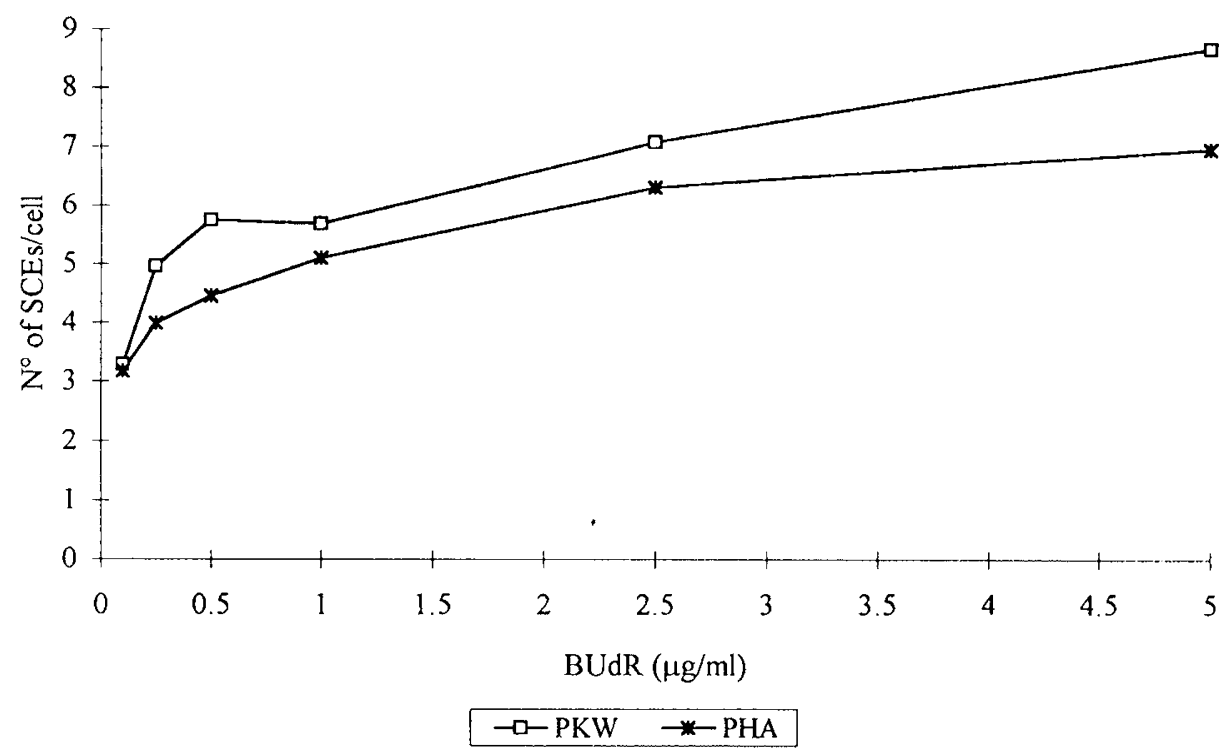

Fig 1. Differential SCE/cell dose-response relationships between PHA and PKW stimulated goat lymphocytes exposed to increasing doses of BUdR. 
increase more slowly and regularly compared to PKW ones, which increase more rapidly from 0.1 to $0.5 \mu \mathrm{g} / \mathrm{ml}$ of BUdR, remain fairly constant from 0.5 to $1 \mu \mathrm{g} / \mathrm{mL}$, and increase again up to $5 \mu \mathrm{g} / \mathrm{mL}$. By extrapolating the two curves beyond the dosage of $5 \mu \mathrm{g} / \mathrm{mL}$, the SCE/cell values scored on PKW stimulated lymphocytes would likely continue to remain higher compared to those for PHA.

In order to verify whether the number of cells examined would have any significant effect on the estimated means we extended the observations to 50 more second cycle metaphase plates at dosages of 0.1 and $5.0 \mu \mathrm{g} / \mathrm{mL}$ of BUdR. By doubling the number of observations from 50 to 100 the 'means' estimated over the first 50 do not change significantly.

In order to study the variation in the SCE/cell distributions within the cell populations, only the lowest and the highest dosages were selected and the individual SCE/cell values were scored on 100 cells for each donor and pooled, summing up to 400 cells for each BUdR level.

Figure 2 shows the observed (obs), Poisson expected (exp) and Poisson 'mixture' expected (exp a) SCE/cell distributions at 0.1 and $5 \mu \mathrm{g} / \mathrm{mL}$ of BUdR, respectively, for PHA and PKW stimulated lymphocytes.

PHA

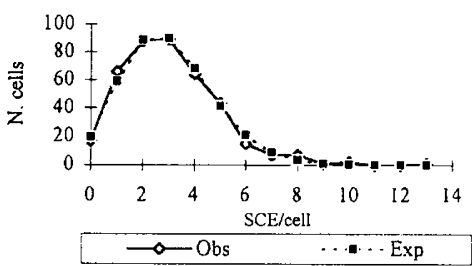

PKW

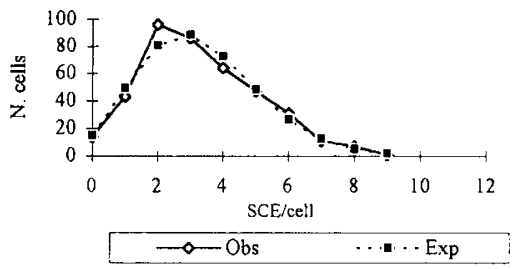

$\mathrm{BUdR}=0.1 \mu \mathrm{g} / \mathrm{ml}$
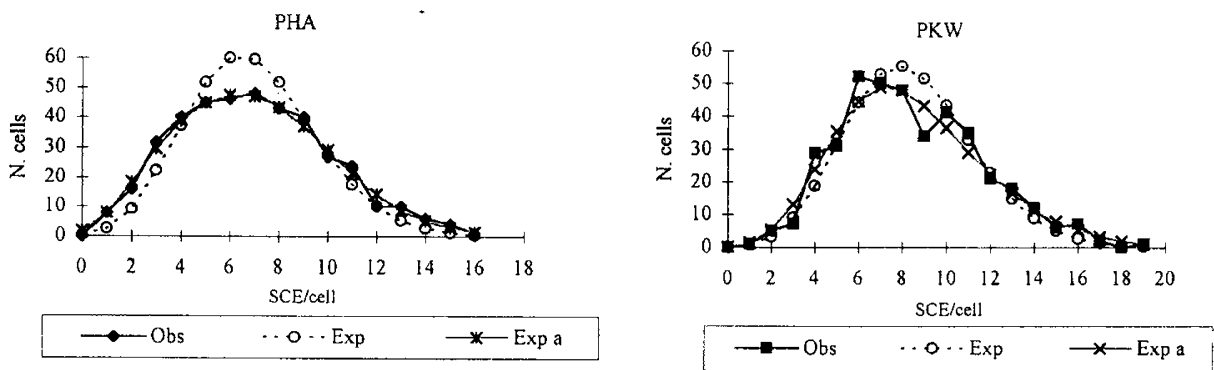

$\mathrm{BUdR}=5.0 \mu \mathrm{g} / \mathrm{ml}$

Fig 2. SCE/cell distributions at 0.1 and $5.0 \mu \mathrm{g} / \mathrm{mL}$ of BUdR, respectively, for PHA and PKW stimulated lymphocytes (Exp = Poisson expectations; Exp a = Poisson 'mixture' expectations).

At $0.1 \mu \mathrm{g} / \mathrm{mL}$ of BUdR both mitogens behave in a similar fashion, and the Poisson frequencies fit very well (chi square $=15.31$ for PHA and 6.98 for PKW; chi square $0.05=18.3$ and 15.5 , respectively). At high BUdR levels $(5 \mu \mathrm{g} / \mathrm{mL})$ the two 
mitogens deviate significantly in their behaviour, and the Poisson frequencies do not fit anymore (chi square $=49.3$ for PHA and 28.61 for PKW; chi square $0.05=25$ and 26.3, respectively). However, when the SCE expected frequencies are calculated on the basis of a Poisson 'mixture' function, they again fit the observed frequencies (chi square $=5.4$ and 13.56 for PHA and PKW, respectively: adjusted $R^{2}=0.98$ and 0.94 , respectively).

\section{DISCUSSION}

The results of the present study clearly indicate that at $0.1 \mu \mathrm{g} / \mathrm{mL}$ of BUdR, the two mitogens have $\mathrm{SCE} /$ cell rates that are strikingly similar to each other, and the Poisson model fit very well the observed frequencies. Since BUdR concentrations lower than $0.1 \mu \mathrm{g} / \mathrm{mL}$ do not allow a clear differential staining between the sister chromatids (Kato, 1974), it is likely that the exchanges observed at this dosage are not BUdR induced or they are so only to a minimum extent. Previous data on the estimation of the spontaneous rate of sister chromatid exchanges in cattle (Di Berardino et al, 1995) and goat (Di Berardino et al, 1996) have shown that 0.1 $\mu \mathrm{g} / \mathrm{mL}$ of BUdR can be considered very close to the level of spontaneous SCEs.

From $0.25 \mu \mathrm{g} / \mathrm{mL}$ up to $5 \mu \mathrm{g} / \mathrm{mL}$ of BUdR, pokeweed stimulated goat lymphocytes exhibit SCE/cell rates significantly higher compared to phytohemagglutinin. As shown in figure 1, by extrapolating the two curves beyond $5 \mu \mathrm{g} / \mathrm{mL}$ of BUdR, up to 10 or even $20 \mu \mathrm{g} / \mathrm{mL}$, which represent the dosages mostly used for SCE studies, the mean SCE/cell rates scored on PKW stimulated lymphocytes would continue to remain higher compared to those achieved on PHA. One of the most reasonable explanations for such a difference can be found on the different cell targets of the two mitogens: PHA, in fact, stimulates mainly $\mathrm{T}$ cells, while PKW stimulates both $\mathrm{T}$ and $\mathrm{B}$ cells. Extensive SCE data on B and T human lymphocytes are reported by Santesson et al (1979) and by Lindblad and Lambert (1981) who found significantly 'higher' SCE/cell values correlated with 'lower' proliferation rates in T compared to B lymphocytes. The authors stated that the major determinant of the SCE/cell frequency may not simply be the proportion of $\mathrm{B}$ and $\mathrm{T}$ lymphocytes in the peripheral blood but the rate of cell proliferation in the culture system; this conclusion, however, has been confuted by other researchers who found no correlation between SCE/cell frequency and cell cycle (Giulotto et al, 1990; Loveday et al, 1990; Steinel et al, 1990; Catalan et al, 1994). As suggested by Kato and Sandberg (1977), and by Lindblad and Lambert (1981), such a discrepancy might be accounted for by the presence of different subpopulations or clones, within the B and T lymphocytes, differing in BUdR sensitivity or other SCE inducing factors, which may further contribute to the enhancement of the variability normally observed in the SCE results.

At $5 \mu \mathrm{g} / \mathrm{mL}$ of BUdR, ie, under the conditions of BUdR-SCE induction, the Poisson model does not fit the observed frequencies, unless a 'mixture' model is used. This finding may provide an explanation for discrepancies with SCE data previously reported by other authors in PKW stimulated blood lymphocytes. Di Meo et al (1993) in goat lymphocytes exposed to $10 \mu \mathrm{g} / \mathrm{mL}$ of BUdR reported on 30 animals, for a total of 902 cells, an average of $6.62 \pm 3.05 \mathrm{SCE} / \mathrm{cell}$, which is lower than the level of $8.68 \pm 3.24 \mathrm{SCE} /$ cell we observed at $5 \mu \mathrm{g} / \mathrm{mL}$ of BUdR; 
furthermore, the authors reported that the SCE/cell frequencies did not follow the Poisson distribution, as we also report here. Probably, even in that case, a Poisson 'mixture' would have fit properly, if tested. The same considerations hold for the SCE data reported in cattle and river buffalo by Iannuzzi et al (1988, 1991a,b). The present data are also slightly higher compared to those reported by Sanchez and Burguete (1992) on the spanish Murciano-Granadina breed of goat, but since they only examined one donor, their study can be considered only as indicative.

In conclusion, the data presented herein show that, under BUdR dosages normally utilized for 'in vitro' SCE studies, ie, from 5 to $20 \mu \mathrm{g} / \mathrm{mL}$ (final concentration): (a) the $\mathrm{SCE} /$ cell rates based on PHA stimulated lymphocytes might be underestimated compared to PKW and vice versa; (b) the Poisson 'mixture' probability function is more suitable than the simple Poisson to describe the SCE/cell distribution. These considerations may be of some importance when comparisons are to be made between SCE data obtained in different laboratories using one mitogen or the other. In our opinion, however, the $\mathrm{SCE} /$ cell rates shown by $\mathrm{PKW}$ should be considered more meaningful than those obtained with PHA, being representative of the entire population of $\mathrm{B}$ and $\mathrm{T}$ lymphocytes and, therefore, of the whole individual.

SCE studies, alone or in conjunction with chromatid/chromosome aberrations and micronuclei, are of great importance in the domestic animal industry, because they allow detection of genotoxic effects induced by environmental mutagens such as mycotoxins, pesticides, heavy metals, and so on, which may affect not only the animals but also the human workers, directly or through possible residues in foodstuffs of animal origin (Rubes, 1987). Breeding animals, expecially those utilized in artificial insemination, should be checked and also selected on the basis of the $\mathrm{SCE} /$ cell rate, in order to eliminate the risk of spreading genetically unstable genotypes into the population, thus compromising the genetic improvement programs.

\section{ACKNOWLEDGEMENT}

We thank C Vitale of the Department of Statistics, University of Salerno, for his valuable collaboration in statistical analysis.

\section{REFERENCES}

Carrano AV, Thompson LH, Lindl PA, Minkler JL (1978) Sister chromatid exchange as an indicator of mutagenesis. Nature 271, 551-553

Catalan J, Moreno C, Arruga MV (1994) Distribution and sources of variability of sister chromatid exchange frequencies in cattle. Genet Sel Evol 26, 3-14

Chaganti RSK, Schonberg S, German J (1974) A many fold increase in sister chromatid exchanges in Bloom's syndrome lymphocytes. Proc Natl Acad Sci, USA 71, 4508-4512

Das BC, Sharma T (1983) Reduced frequency of baseline sister chromatid exchanges in lymphocytes grown in antibiotics and serum-excluded culture medium. Hum Genet 64 , 249-253

Di Berardino D, Lioi MB, Scarfi MR, Jovino V, Marigliano P (1995) Spontaneous sister chromatid exchanges in mitotic chromosomes of cattle (Bos taurus L). Genet Sel Evol $27,385-393$

Di Berardino D, Jovino V, Lioi MB, Scarfi MR, Burguete I (1996) Spontaneous rate of sister chromatid exchanges (SCEs) and BrdU dose-response relationships in mitotic chromosomes of goat (Capra hircus L). Hereditas 124, 137-143 
Di Meo GP, Iannuzzi L, Perucatti A, Ferrara L, Pizzillo M, Rubino R (1993) Sister chromatid exchange in the goat (Capra hircus L). Hereditas 118, 35-38

Giulotto E, Mottura A, Giorgi R, Carli L, Nuzzo F (1990) Frequencies of sister chromatid exchanges in relation to cell kinetics in lymphocyte cultures. Mutat Res 70, 343-350

Iannuzzi L, Perucatti A, Di Meo GP, Ferrara L (1988) Sister chromatid exchange in chromosomes of river buffalo (Bubalus bubalis L). Caryologia 41, 237-244

Iannuzzi L, Di Meo GP, Perucatti A, Ferrara L, Gustavsson I (1991a) Sister chromatid exchange in chromosomes of cattle from three different breeds reared under similar conditions. Hereditas 114, 201-205

Iannuzzi L, Di Meo GP, Perucatti A, Ferrara L, Gustavsson I (1991b) Sister chromatid exchange in cattle marker chromosomes. Caryologia 44, 145-152

Ikushima T, Wolff S (1974) Sister chromatid exchanges induced by light flashes to 5-bromodeoxyuridine and 5-iododeoxyuridine substituted Chinese hamster chromosomes. Exp Cell Res 87, 15-19

Kato H (1974) Spontaneous sister chromatid exchanges detected by a BrdU labelling method. Nature 251, 70-72

Kato H (1977) Spontaneous and induced sister chromatid exchanges as revealed by the BUdR-labelling method. Int Rev Cytol 49, 55-97

Kato H, Sandberg AA (1977) The effect of sera on sister chromatid exchanges in vitro. Exp Cell Res 109, 445-448

Lindblad A, Lambert B (1981) Relation between sister chromatid exchange, cell proliferation and proportion of B and T cells in human lymphocyte cultures. Hum Genet 57, $31-34$

Loveday KS, Anderson BE, Resnick MA, Zeiger E (1990) Chromosome aberration and sister chromatid exchange test in Chinese hamster ovary cells in vitro. V: Results with 46 chemicals. Environ Mol Mutagen 16, 272-303

Mutchinick O, Ruz I, Casas L (1980) Time of first-generation metaphases. I. The effect of various culture media and fetal calf serum in human lymphocyte cultures. Mutat Res $72,127-134$

Rooney D, Czepulkowski B (1986) Human Cytogenetics: a Practical Approach. IRL Press, Oxford

Rubes J (1987) Chromosomal aberrations and sister chromatid exchanges in swine. Mutat Res 191, 105-109

Sanchez C, Burguete I (1992) Sister chromatid exchange on the goat. Proc 10th Eur Coll Cytogenet Dom Anim, Utrecht University, The Netherlands, 218-222

Santesson B, Lindhal-Kiessling K, Mattsson A (1979) SCE in B and T lymphocytes. Possible implications for Bloom's syndrome. Clin Genet 16, 133-135

Snope AJ, Rary JM (1979) Cell-cycle duration and sister chromatid exchange frequency in cultured human lymphocytes. Mutation Res 63 , 345-349

Soper KA, Stalley PD, Galloway SM, Smith JG, Nichols WW, Wolman SR (1984) Sister chromatid exchange (SCE) report on control subjects in a study of occupationally exposed workers. Mutat Res $129,77-88$

Speit G (1980) Effects of temperature on sister chromatid exchanges. Hum Genet 55, $333-336$

Steinel HH, Arlauskas A, Baker RSU (1990) SCE induction and cell-cycle delay to toxaphene. Mutat Res 230, 29-33

Wolff S, Perry P (1974) Differential Giemsa staining of sister chromatids and the study of sister chromatid exchanges without autoradiography. Chromosoma (Berl) 48, 341-353

Wulf HC, Kromann N, Kausgaard N, Hansen JC, Niebuhr E, Algoge K (1986) Sister chromatid exchange (SCE) in Greenlandic Eskimoes. Dose-response relationship between SCE and seal diet, smoking, and blood cadmium and mercury concentrations. Sci Total Environ 48, 81-94 